\title{
ХАРАКТЕРИСТИКА ЕПІДЕМІЧНОГО ПРОЦЕСУ COVID-19 ПІД ЧАС ДРУГОЇ ХВИЛІ ПІДЙОМУ ЗАХВОРЮВАНОСТІ В УКРАЇНІ
}

\author{
ДУ «Інститут епідеміології та інсрекційних хвороб ім. Л.В. Громашевського НАМН України»
}

Мета - встановлення особливостей епідемічного процесу COVID-19 в Україні в період другої хвилі підйому її захворюваності.

Матеріали і методи. Проведено порівняльний аналіз епідемічного процесу COVID-19 в Україні на початку 2021 р. та під час нового підйому захворюваності (другої хвилі) за матеріалами офріційної звітності.

Результати досліджень та їх обговорення. Перша хвиля епідемічного процесу COVID-19 в Україні тривала до кінця перших 2 тижнів 2021 р. Починаючи з 7-го тижня року, можна констатувати підйом захворюваності 2-ї хвилі з максимумом на 13-14-у тижні (тижневі показники захворюваності становили 271,7276,3 на 100 тис. населення); із 15-го тижня (через 1 тиждень після введення з 5 квітня 2021 р. локдауну в більшості регіонів України) почалося ії зниження; із 21го тижня 2021 р. можна говорити про припинення другої хвилі підйому захворюваності. Захворюваність на COVID-19 достовірно корелювала у часі із загальною захворюваністю на ГРВІ $(r=0,88 \pm 0,05)$, і можна опосередковано говорити про гіподіагностику COVID-19. Мінімальні щотижневі показники смертності від COVID-19 спостерігалися на 6-7-му та 22-му тижнях року (2,0 на 100 тис. населення), максимальні - на 1415-му тижнях (7,1 на 100 тис. населення). Сумарна летальність протягом 01.01-06.06.2021 р. зросла з 1,8 до 2,3 \%, а щотижнева летальність протягом 17-22го тижнів стабільно перевищувала 4,0 \% та мала тенденцію до зростання. Серед пацієнтів вікових груп 60-69 років та 70 років і старше наприкінці другої хвилі сумарна летальність перевищувала значення середнього показника серед загальної кількості пацієнтів (2,33 \%) відповідно в 1,6 та 4,8 разу. Частка пацієнтів, в яких методом ПЛР підтверджено діагноз COVID-19, коливалася від 4,8 до 33,4 \% з найменшими рівнями, починаючи з 18-го тижня, на тлі значного зниження захворюваності другої хвилі.

Висновки. Можна говорити про прискорення передачі SARS-CoV-2 під час другого підйому захворюваності на COVID-19 в Україні порівняно з першою хви- лею. За результатами епідеміологічного аналізу офріційних статистичних даних, за період нової епідемічної хвилі (7-20-й тижні) не відбулося значних змін особливостей епідемічного процесу цієї інфрекції, за винятком його різкої інтенсифрікації, що призвело до перевантаження системи охорони здоров'я, зростання летальності (головним чином за рахунок пацієнтів віком від 60 років, на яких припадало 81,72 \% летальних випадків при їх частці серед захворілих 29,15 \%). Показники сумарної летальності підвищувалися через 2-3 тиж після зростання співвідношення кількості захворілих до кількості госпіталізованих до рівня 2,7 та вище. Дані офріційної статистики щодо захворюваності на COVID-19 занижені. За епідеміологічними ознаками підтвердження збільшення вірулентності SARS-CoV-2 не виявлено.

Ключові слова: COVID-19, епідемічний процес, захворюваність, смертність, летальність.

У той час, коли ВООЗ 11 березня 2020 р. оголосила пандемію, у світі було відомо лише про 118 тис. випадків COVID-19, зареєстрованих у 110 країнах світу. Через рік, 11 березня 2021 р., цей показник збільшився в 1000 разів і становив уже 118916479 випадків, станом на 17 червня - 177819472 випадки. За період, що минув від початку появи нового коронавірусу SARS-CoV-2, у світі спостерігалося 3 хвилі підйому захворюваності на COVID-19 (мал. 1а [1]), у той час, як в Україні - лише дві (мал. 16 [2]) за рахунок жорсткого локдауну, що був запроваджений у березні 2020 р. та тривав понад 2,5 міс.

Остання хвиля захворюваності була більш інтенсивною. Це пов'язано з подальшою еволюцією SARS-CoV-2, а саме формуванням нових його варіантів (британського - альфа, південно-африканського - бета, бразильського - гамма, індійського - дельта та інших), у яких відбулися мутації в гені, що кодує S-білок, а особливо його фррагмент - рецепторзв'язувальний домен (RBD), що пришвидшило розповсюдження збудника через полегшення його зв'язування з рецепторами клітин (головним чином, із ангіотензинперетворювальним фермен- 
том 2 - ACE2) та могло вплинути на інші властивості, зокрема антигенні [3-6]. Крім того, мутації в інших генах також могли знизити ефективність виявлення вірусу вже існуючими комерційними тест-системами [7]. Прикладом нового варіанту вірусу є його індійська лінія В.1.617, що має загальні ключові мутації D111D, G142D, L452R, E484Q, D614G i P681R у S-білку, у тому числі й у RBD
[8]. Мутації в положеннях залишків 452, 484 і 681 описані також у вірусів SARS-CoV-2 інших широко циркулюючих ліній. Структурний аналіз мутацій RBD L452R i E484Q разом із P681R у сайті розщеплення фрурином дає підставу передбачати можливість підвищення зв'язування 3 ACE2, швидкості розщеплення S1-S2 i, відповідно, швидшу передачу вірусу.

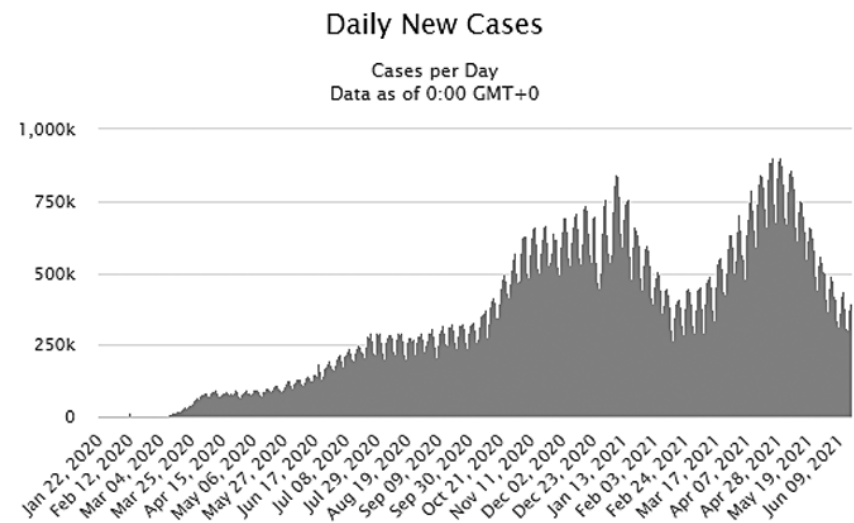

UKRAINE COVID-19 DAILY SITUATION REPORT June 17, 2021;09:00

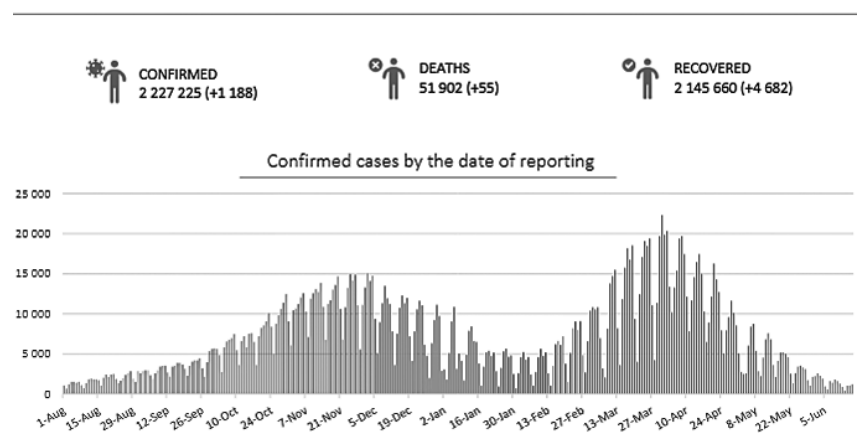

6

Мал. 1. Нові щоденні випадки COVID-19 у світі (а) [1] та в Україні (б) [2].

Частіше фрормування нових варіантів вірусу відбувається на певних територіях, але їх подальше розповсюдження в глобальному масштабі не вдається стримати тими протиепідемічними заходами, які натепер застосовуються у світі. Дослідженнями, проведеними в ДУ «Інститут епідеміології та інфекційних хвороб ім. Л.В. Громашевського НАМН України», вперше в Україні було виявлено британський варіант SARS-CoV-2 та показано його циркуляцію в країні із середини лютого 2021 р. Саме на цей період припадає й початок другої хвилі захворюваності на COVID-19.

Метою роботи було визначити особливості епідемічного процесу COVID-19 в Україні у період другої хвилі підйому її захворюваності.

\section{Матеріали і методи}

У роботі було проаналізовано «Щоденні звіти про ситуацію з COVID-19 в Україні», «Оперативні довідки про основні показники захворюваності на COVID-19 в Україні», щотижневі звіти «Епідемічна ситуація із захворюваності на COVID-19 в Україні» за 1-22-й тижні 2021 р. Центру громадського здоров'я МОЗ України (далі - ЦГЗ) за період з 01.01 по 06.06.2021 р. та Інформаційні бюлетені Центру грипу та ГРВІ ЦГЗ за період з 01.01 по 23.05.2021 р. Порівняно деякі епідеміологічні особливості COVID-19 на початку 2021 р. та під час нового підйому її захворюваності.

\section{Результати досліджень та їх обговорення}

Згідно з офріційними статистичними даними захворюваності на COVID-19, перші 2 тижні 2021 р. були останніми, які відносилися до першої хвилі підйому захворюваності на цю інфекцію (мал. 2). Показники тижневої захворюваності становили відповідно 107,8 та 116,6 на 100 тис. населення. Наступні 4 тижні характеризувалися стабільністю її рівнів (67,0-80,4 на 100 тис. населення). Підйом захворюваності другої хвилі розпочався, починаючи з 7-го тижня (89,8 на 100 тис. населення). Вона досягла максимуму на 13-14-й тиждень (відповідно 271,7-276,3), із 15-го тижня (12-18 квітня) почалося її зниження $(241,3)$, тобто через 1 тиждень після введення 35 квітня 2021 р. локдауну в більшості регіонів України. На 19-й тиждень показник захворюваності наблизився до рівня 7-го тижня і становив 88,4, на 20-й тиждень - 73,1, після чого продовжував знижуватися і протягом 21-22-го тижнів досяг значення 48,9 та 33,0 на 100 тис. населення відповідно на кінець 22-го тижня року. Таким чином, можна говорити про припинення другої хвилі підйому захворюваності на COVID-19, починаючи з 21-го тижня 2021 р. 


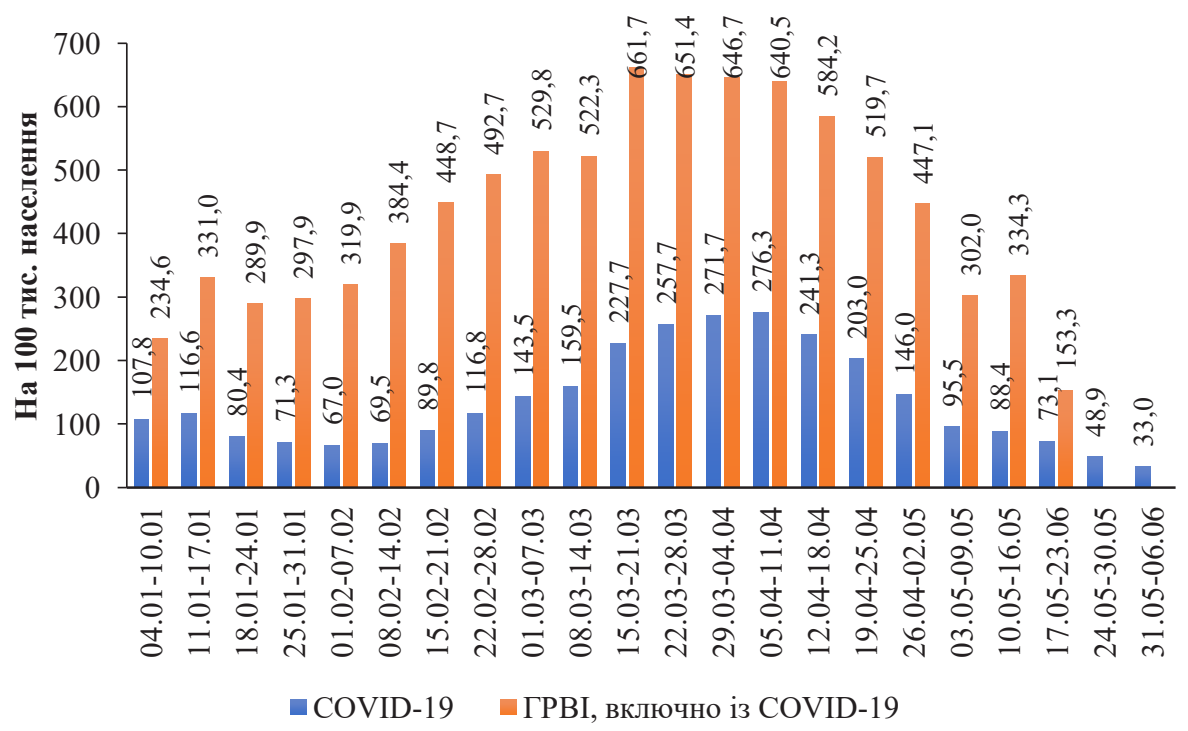

Мал. 2. Динаміка тижневої захворюваності на COVID-19 та ГРВІ в Україні протягом 01.01-06.06.2021 р.

У загальній захворюваності на ГPBI частка COVID-19 протягом періоду спостереження 2021 р. (20 тижнів) коливалася від $18 \%$ у лютому (08.02-14.02) до $48 \%$ у травні (17.05-23.06). Коефіцієнт кореляції (r) між загальною захворюваністю на ГРВІ та захворюваністю на COVID-19 дорівнював 0,88 $\left(m_{r}= \pm 0,05\right)$, що свідчило про достовірний зв'язок високої сили. Ураховуючи той фракт, що від початку пандемії COVID-19 віруси грипу в Україні виявлялися лише в поодиноких випадках, так само як і інші респіраторні віруси, можна припустити, що більша частка ГРВI була етіологічно пов'язана із SARS-CoV-2. Зазначене $\epsilon$ опосередкованим свідченням гіподіагностики COVID-19 в Україні.

Якщо порівнювати віковий розподіл захворілих на 1-му і 22-му тижнях 2021 р., то незначне збільшення їх частки відбулося у вікових групах 0-9 років (із 1,7 до 1,9\%), 60-69 років та 70 років і старше (відповідно 317,4 до 18,3 \% та з 8,9 до 10,9 \%) (мал. 3).

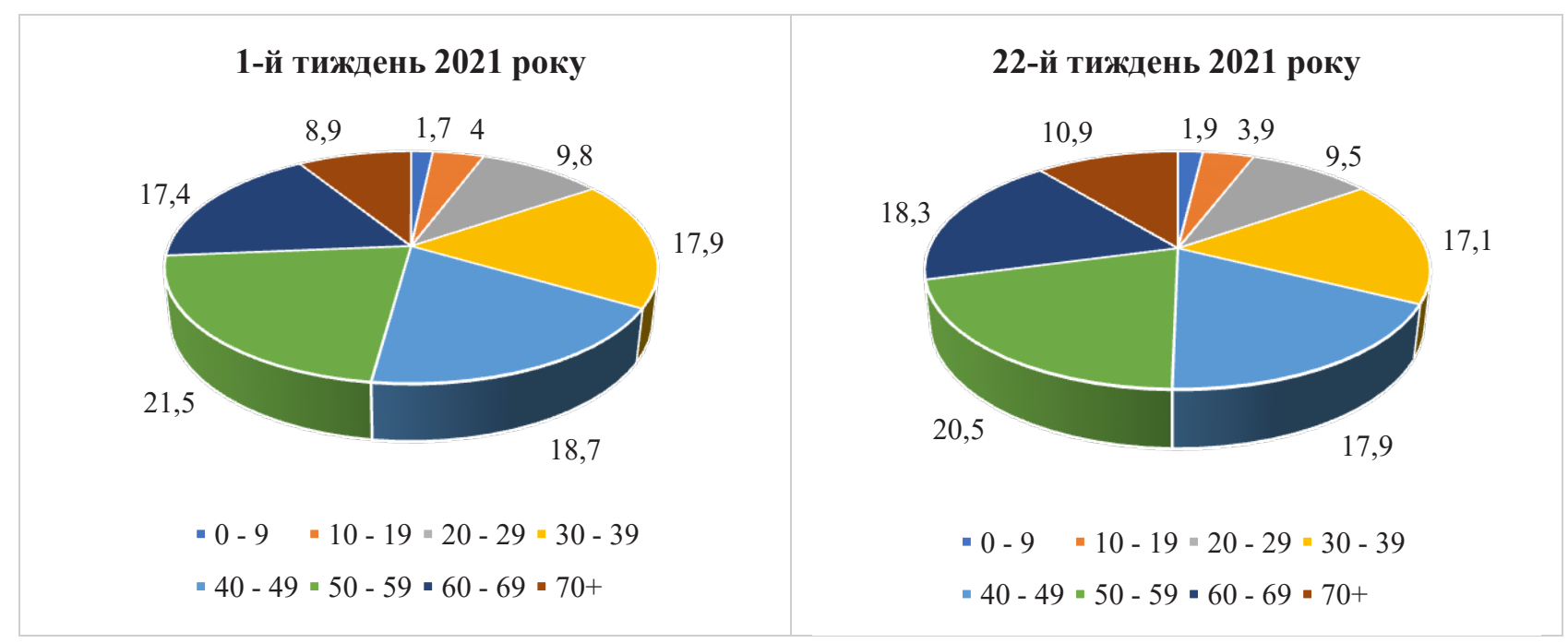

Мал. 3. Вікова структура захворілих на COVID-19 (\%). 


\section{ОРИГІНАЛЬНІ ДОСЛІДЖЕННЯ}

Восени 2020 р. середня частка дітей, розрахована від початку реєстрації COVID-19, дорівнювала 6,6 \%, а медичних працівників - 7,4\% [9]. Протягом 22 тижнів 2021 р. частка дітей (0-17 років) серед загальної кількості захворілих коливалася в межах 2,9-6,7 \%. Найбільшим цей показник був на 7-13-му тижнях, тобто від початку другої хвилі до введення локдауну, що може опосередковано свідчити про роль дітей в інтенсифрікації епідемічного процесу. У 2020 р. за тижнями спостереження останній показник коливався від 2,6 до 4,5 \%. Його зниження пояснюється підвищенням ефективності застосування засобів індивідуального захисту та тим фактом, що значна частка медичних працівників вже перехворіла на COVID-19.

що стосується щотижневих показників смертності від COVID-19, то мінімальне їх значення було на 6-7-му тижнях (по 2,0 випадки на 100 тис. населення), тобто збігалося з останнім тижнем перед початком 2-ї хвилі та першим тижнем її початку, та на 22-у тижні року (мал. 4а). Максимальні показники смертності зареєстровані на 14-15-у тижнях (по 7,1 на 100 тис. населення) 3 відставанням на 1-2 тижні від максимальної захворюваності. Сумарна летальність від COVID-19 протягом 01.01-06.06.2021 р. зросла з 1,8 до 2,3 \%, у той же час щотижнева летальність протягом 17-22-го тижнів стабільно перевищувала 4,0 \% та мала тенденцію до зростання (мал. 4б). Така невідповідність у показниках пов'язана 3 недосконалістю розрахунків щотижневої летальності, оскільки на тлі зниження захворюваності продовжували реєструвати летальні випадки серед тих пацієнтів, які захворіли раніше, зокрема й на піку захворюваності.
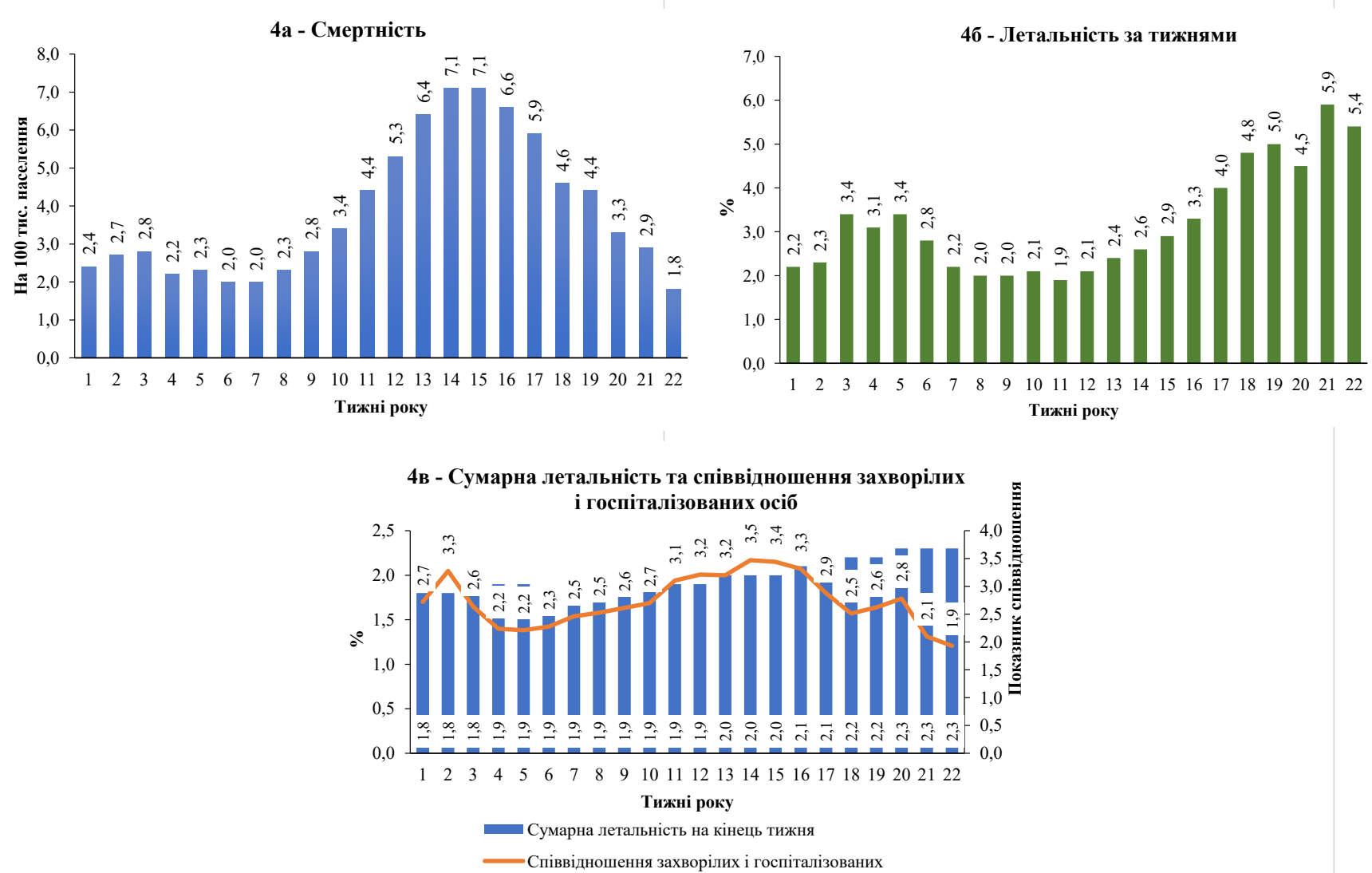

Мал. 4. Динаміка смертності (4a), летальності від COVID-19 за тижнями (4б), сумарної летальності та співвідношення кількості захворілих до кількості госпіталізованих (4в) протягом 01.01-06.06.2021р.

Наприкінці другої хвилі (22-й тиждень) сумарна летальність, що розрахована від початку реєстрації COVID-19, серед пацієнтів вікових груп 60-69 років та 70 років і старше перевищувала значення середнього показника серед загальної кількості пацієнтів (2,33 \%) відповідно в 1,6 та 4,8 разу і становила 3,72 та 11,25 \% (мал. 5). Серед пацієнтів віком 0-9 та 10-19 років вона була в 58,3 та 77,7 разу нижчою (0,04 \% та 0,03 \% від- 
повідно), а у віковій групі 20-29 років - у 29,1 разу (0,08 \%). Якщо простежити сумарну летальність за віковими групами в динаміці, то відбулося незначне зростання ії показника серед вікових груп 30-39, 40-49 та 50-59 років (відповідно на 0,05, 0,11 та 0,19\%). У той же час, серед пацієнтів вікових груп 60-69 років та 70 років і старше ії збільшення було значніше - відповідно на 0,56 та 1,54 \% з початку року. Крім того, частка пацієнтів цих двох вікових груп серед загальної кількості захворілих становила 29,15 \%, у той час, як частка летальних випадків від їх загальної кількості - 81,72 \%. Враховую- чи наведені дані, можна говорити про те, що зростання летальності протягом другої хвилі відбулося саме за рахунок пацієнтів 60 років і старше. Зазначене може бути пов'язано з великим перевантаженням лікарень у той період, що відображалося на своєчасності надання адекватної медичної допомоги. Це підтверджується й показниками співвідношення кількості госпіталізованих до кількості захворілих у динаміці (мал. 4в). Показник сумарної летальності підвищувався через 2-3 тиж після зростання співвідношення кількості захворілих до кількості госпіталізованих до рівня 2,7 і вище.

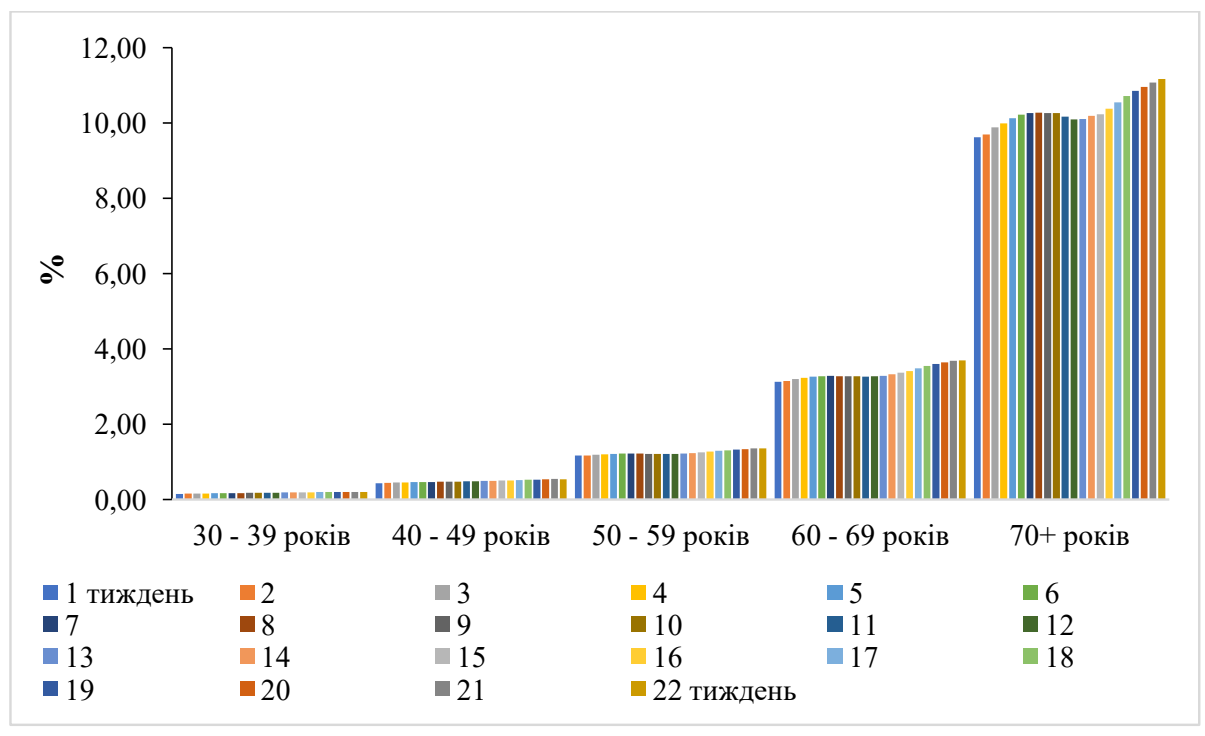

Мал. 5. Динаміка летальності від COVID-19 за віковими групами протягом 01.01-06.06.2021 р.

щотижня від 144248 до 348647 осіб обстежувалися методом ПлР з метою діагностики COVID-19, і найбільша кількість досліджень припадала на 11-14-й тижні, коли реєструвались максимальні показники захворюваності на ГРВІ, включаючи COVID-19. Частка пацієнтів, в яких підтверджено COVID-19 методом ПЛP, від кількості обстежених осіб за тижнями спостереження коливалася в межах 4,8-33,4 \% (мал. 6). Найменші значення цих рівнів були, починаючи $з$ 18-го тижня $(14,5 \% \rightarrow 4,8 \%)$, коли значно знизилася захворюваність другої хвилі. Під час зниження захворюваності в період між першою і другою хвилями ці показники дорівнювали 18,7-21,5 \%. Як і кількість обстежень, частка позитивних результатів мала найбільші значення протягом 11-15-го тижнів. Чим вищими є ці значення, тим більш заниженими є дані офріційної статистики, більш недостатнім $€$ обсяг лабораторного обстеження населення і незадовільною - епідемічна ситуація.

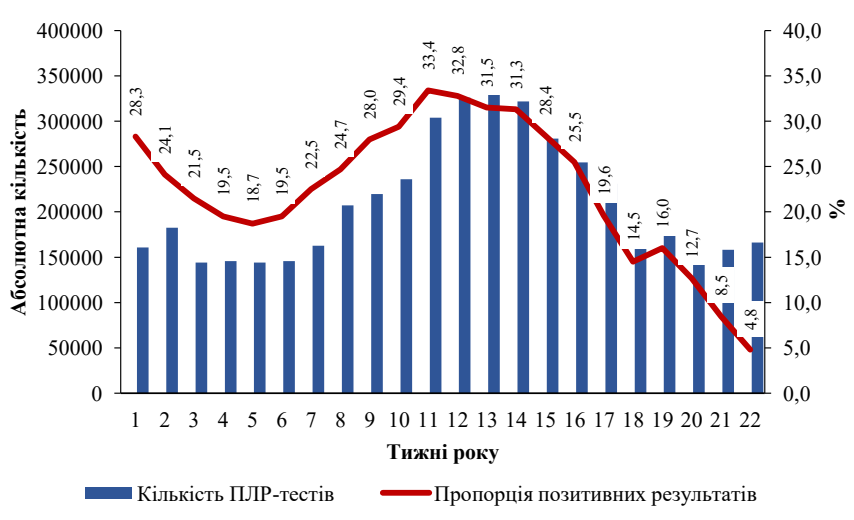

Мал. 6. Динаміка кількості та результативності лабораторних обстежень методом ПлР на COVID-19 протягом 01.0106.06.2021 p. 
Враховуючи наведені дані, можна говорити про прискорення передачі збудника під час другого підйому захворюваності на COVID-19 в Україні порівняно з першою хвилею. Однак за епідеміологічними ознаками будь-якого підтвердження щодо збільшення вірулентності SARS-CoV-2 не виявлено. Такі результати узгоджуються і з даними інших дослідників відносно британського варіанту SARS-CoV-2 (лінія B.1.1.7), які повідомляють про прискорення його розповсюдження на 70 \% порівняно з тими вірусами, що циркулювали раніше, без зміни їх інших властивостей $[10,11]$.

\section{Висновки}

1. Починаючи з 7-го тижня 2021 р., в Україні розпочався другий підйом захворюваності на COVID-19, під час якого було встановлено циркуляцію нового британського варіанту SARS-CoV-2. Він супроводжувався різким зростанням кількості захворілих, госпіталізованих осіб та летальних випадків. Його пік спостерігався на 13-14-й тижні, із 15-го тижня почалося зниження захворюваності (через 1 тиждень після введення локдауну в більшості регіонів України). На 19-й тиждень ії показник наблизився до рівня 7-го тижня.

2. Результати аналізу захворюваності на ГРВІ та COVID-19 у динаміці свідчать про те, що дані офріційної статистики щодо захворюваності на COVID-19 є значно заниженими.

3. Розрахунки щотижневої летальності COVID-19 у період, коли швидко змінюються показники захворюваності, не можна вважати досконалими, оскільки на тлі зниження захворюваності продовжують реєструватися летальні випадки серед тих пацієнтів, які захворіли раніше, що призводить до неправильного тлумачення даних у непрофресійному середовищі.

4. За результатами епідеміологічного аналізу офріційних статистичних даних за період нової епідемічної хвилі (7-20-й тижні 2021 р.), не відбулося значних змін особливостей епідемічного процесу цієї інфекції, за винятком його різкої інтенсифікації, що призвело до перенавантаження системи охорони здоров'я, зростання летальності з 1,8 до 2,3 \% (головним чином, за рахунок пацієнтів віком від 60 років, на яких припадало 81,72 \% летальних випадків при їх частці серед захворілих 29,15 \%) та змусило посилити протиепідемічні заходи. Це свідчить про прискорення передачі збудника. За епідеміологічними ознаками будь-якого підтвердження збільшення вірулентності SARS-CoV-2 не виявлено.

\section{Література}

1. COVID-19 coronavirus pandemic: Last updated: June 17, 2021, 08:01 GMT. Wordometer. Електронний ресурс. -Access mode: https://www.worldometers.info/coronavirus/

2. Ukraine COVID-19 daily situation report June: 17, 2021, 09:00. Центр Громадського здоров я МОЗ України. Електронний ресурс. Отримано 3: https://cloud.phc.org.ua/index.php/ s/72wxF7jNnrBx492?path= \%2F2021.06\#pdfviewer

3. Задорожна В.І. Молекулярно-епідеміологічні аспекти SARS-COV-2 / В.I. Задорожна // Інфекційні хвороби - 2021. - № 1. - C. $32-44$

4. The Impact of Mutations in SARS-CoV-2 Spike on Viral Infectivity and Antigenicity / Q. Li, J. Wu, J. Nie [et al.] // Cell. - 2020. - Vol. 182(5). - P. 1284-1294.

5. SARS-CoV-2 Variant Classifications and Definitions: Updated June 15, 2021. CDC. Електронний ресурс. Отримано 3: https://www.cdc.gov/coronavirus/2019-ncov/variants/variant-info.html

6. Disease Outbreak News: SARS-CoV-2 Variants: Originally published 31 Dec 2020. WHO. Електронний ресурс. Отримано з: https://reliefweb.int/report/world/disease-outbreak-news-sars-cov-2variants-31-december-2020

7. A novel point mutation in the $\mathrm{N}$ gene of SARS-CoV-2 may affect the detection of the virus by reverse transcription-quantitative
PCR / M. R. Hasan, S. Sundararaju, C. Manickam [et al.] // J. Clin. Microbiol. - 2020. - Vol. 59(4). - P. e03278-20.

8. Convergent evolution of SARS-CoV-2 spike mutations, L452R, E484Q and P681R, in the second wave of COVID-19 in Maharashtra, India / S. Cherian, V. Potdar, S. Jadhav [et al.] // bioRxiv. - 2021.04.22.440932.

9. Задорожна B.I. Епідеміологічні аспекти COVID-19 та проблемні питання / В.І. Задорожна, Т.А. Сергеєва // Актуальна інсектологія. - 2020. - Т. 8, № 5-6. - С. 141-143.

10. The British variant of the new coronavirus-19 (Sars-Cov-2) should not create a vaccine problem / P. Conti, A. Caraffa, C.E. Gallenga [et al.] // J. Biol. Regul. Homeost. Agents. - 2021. - Vol. 35 (1). - P. 1-4.

11. Genomic characteristics and clinical effect of the emergent SARS-CoV-2 B.1.1.7 lineage in London, UK: a whole-genome sequencing and hospital-based cohort study / D. Frampton, T. Rampling, A. Cross [et al.] // Lancet Infect. Dis. - 2021. - Apr 12:S14733099(21)00170-5. doi: 10.1016/S1473-3099(21)00170-5. Epub ahead of print. PMID: 33857406; PMCID: PMC8041359. 


\section{References}

1. COVID-19 coronavirus pandemic: Last updated: June 17, 2021, 08:01 GMT. Wordometer. Electronic resource. Retrieved from: https://www.worldometers.info/coronavirus/

2. Ukraine COVID-19 daily situation report June: 17, 2021, 09:00. Center for Public Health of the Ministry of Health of Ukraine. Electronic resource. Retrieved from: https://cloud.phc.org.ua/index. php/s/72wxF7jNnrBx492?path= \%2F2021.06\#pdfviewer

3. Zadorozna, V. I. (2021). Molecular and epidemiological aspects of SARS-CoV-2. Infectsiyni khvoroby - Infectious Diseases, (1), 32-44. Retrieved from: https://doi.org/10.11603/16812727.2021.1.11949 [in Ukrainian]

4. Li, Q., Wu, J., Nie, J., Zhang, L., Hao, H., Liu, S., Zhao, C., Zhang, Q., et al. (2020). The Impact of Mutations in SARS-CoV-2 Spike on Viral Infectivity and Antigenicity. Cell, 182 (5), 1284-1294. e9. Retrieved from: https://doi.org/10.1016/j.cell.2020.07.012

5. SARS-CoV-2 variant classifications and definitions: Updated June 15, 2021. CDC. Electronic resource. Retrieved from: https://www. cdc.gov/coronavirus/2019-ncov/variants/variant-info.html

6. Disease Outbreak News: SARS-CoV-2 Variants: Originally published 31 Dec 2020. WHO. Electronic resource. Retrieved from: https://reliefweb.int/report/world/disease-outbreak-news-sars-cov-2variants-31-december-2020

7. Hasan, M. R., Sundararaju, S., Manickam, C., Mirza, F., AlHail, H., Lorenz, S., \& Tang, P. (2021). A novel point mutation in the N gene of SARS-CoV-2 may affect the detection of the virus by reverse transcription-quantitative PCR. Journal of Clinical Microbiology, 59 (4), e03278-20. Retrieved from: https://doi.org/10.1128/JCM.03278-20

8. Cherian, S., Potdar, V., Jadhav, S., Yadav, P., Gupta, N., Das, M., Das, S., Agarwal, A., Singh, S., Abraham, P., Panda, S., Mande, S., Swarup, R., Bhargava, B., Bhushan, R., \& NIC team, INSACOG Consortium (2021). Convergent evolution of SARS-CoV-2 spike mutations, L452R, E484Q and P681R, in the second wave of COVID-19 in Maharashtra, India. bioRxiv 2021.04.22.440932; DOI: h ttps://doi.org/10.1101/2021.04.22.440932

9. Zadorozhna, V.I., Serheieva, T.A. (2020). Epidemiological aspects of COVID-19 and problematic issues. Actual Infectology, 8 (5-6), 141-143 [in Ukrainian].

10. Conti, P., Caraffa, A., Gallenga, C. E., Kritas, S. K., Frydas, I., Younes, A., Di Emidio, P., Tetè, G., Pregliasco, F., \& Ronconi, G. (2021). The British variant of the new coronavirus-19 (Sars-Cov-2) should not create a vaccine problem. Journal of Biological Regulators and Homeostatic Agents, 35 (1), 1-4. Retrieved from: https://doi. org/10.23812/21-3-E

11. Frampton, D., Rampling, T., Cross, A., Bailey, H., Heaney, J., Byott, M., Scott, R., et al. (2021). Genomic characteristics and clinical effect of the emergent SARS-CoV-2 B.1.1.7 lineage in London, UK: a whole-genome sequencing and hospital-based cohort study. The Lancet. Infectious Diseases, S1473-3099(21)00170-5. Advance online publication. https://doi.org/10.1016/S1473-3099(21)00170-5

\section{CHARACTERISTICS OF THE COVID-19 EPIDEMIC PROCESS DURING THE SECOND WAVE OF ITS RISE IN UKRAINE}

\author{
V.I. Zadorozhna, T.A. Serheyeva
}

L.V. Gromashevsky Institute of Epidemiology and Infectious Diseases, National Academy of Medical Science of Ukraine

SUMMARY. The aim of the study is to determine the peculiarities of the COVID-19 epidemic process in Ukraine during the second wave of its incidence.

Materials and methods. A comparative analysis of the epidemic process of COVID-19 in Ukraine in early 2021 and during the new rise in morbidity (second wave) according to official reports.

Results and discussion. The first wave of the COVID-19 epidemic process in Ukraine lasted until the end of the first 2 weeks of 2021. Starting from the 7th week of the year it is possible to state the rise in the incidence of the second wave with a maximum at weeks 13-14 (weekly incidence rates were 271.7-276.3 per 100 thousand population). From the 15th week (1 week after the introduction of the lockdown in most regions of Ukraine on April 5, 2021) its decrease began; from the week 21 of 2021, we can talk about the cessation of the second wave of rising morbidity. The incidence of COVID-19 was significantly correlated in time with the overall incidence of $A R I(r=0.88 \pm 0.05)$, and we can indirectly talk about the underdiagnosis of COVID-19. The minimum weekly mortality rates from COVID-19 observed in weeks 6, 7 and 22 of the year (2.0 per 100 thousand population), the maximum - in weeks 14-15 (7.1 per 100 thousand population). The total mortality during 01.01-06.06.2021 increased from 1.8 \% to $2.3 \%$, and the weekly mortality during weeks 17-22 steadily exceeded $4.0 \%$ and tended to increase. Among patients aged 60-69 and 70 and older at the end of the second wave, the total mortality exceeded the mean value among the total number of patients (2.33\%) by 1.6 and 4.8 times, respectively. The proportion of patients diagnosed with COVID-19 by PCR ranged from $4.8 \%$ to $33.4 \%$ with the lowest levels from week 18, with a significant reduction in the incidence of the second wave. Conclusions. We can talk about the acceleration of SARS-CoV-2 transmission during the second rise in the incidence of COVID-19 in Ukraine compared to the first wave. According to the results of epidemiological 
analysis of official statistics for the period of the new epidemic wave (7-20 weeks), there were no significant changes in the epidemic process of this infection, except for its sharp intensification, which led to overload of the health care system, increased mortality. According to the results of epidemiological analysis of official statistics for the period of the new epidemic wave (7-20 weeks), there were no significant changes in the epidemic process of this infection. At the same time, it sharply intensified, which led to an overload of the health care system and an increase in mortality (mainly due to patients over 60 years of age, who accounted for $81.72 \%$ of deaths with their share among patients $29.15 \%)$. The total mortality rate increased in 2-3 weeks after the increase in the ratio of the number of patients to the number of hospitalized to the level of 2.7 and above. The official incidence statistics for COVID-19 are underestimated. According to epidemiological signs, no evidence of increased virulence of SARS-CoV-2 virus detected.

Key words: COVID-19; epidemic process; morbidity; death rate; mortality.

\section{Відомості про авторів:}

Задорожна В.І. - член-кореспондентка НАМН України, д. мед. н., профресорка, директорка ДУ «Інститут епідеміології та інфекційних хвороб ім. Л.В. Громашевського НАМН України»; e-mail: viz2010@ukr.net

ORCID iD: https://orcid.org/0000-0002-0917-2007

Сергеєва Т.А. - д. мед. н., ст. н. с., завідувачка лабораторії епідеміології парентеральних вірусних гепатитів та ВІЛ-інфекції; e-mail: tas1960@ukr.net

ORCID iD: https://orcid.org/0000-0001-6488-4042

\section{Information about the authors:}

Zadorozhna V.I. - Corresponding Member of the National Academy of Medical Sciences of Ukraine, MD, Professor, Director of the State Institution "L.V. Hromashevskyi Epidemiology and Infectious Diseases Institute of the National Academy of Medical Sciences of Ukraine"; e-mail: viz2010@ ukr.net

ORCID iD: https://orcid.org/0000-0002-0917-2007

Serheieva T.A. - MD, Senior Researcher, Head of the Laboratory of Epidemiology of Parenteral Viral Hepatitis and HIV-infection; e-mail: tas1960@ukr.net

ORCID iD: https://orcid.org/0000-0001-6488-4042

Конфрлікту інтересів немає.

The authors have no conflicts of interests to declare.

Отримано 29.06.2021 р. 